\title{
Slip Casting of Alumina for Membrane Application
}

\author{
B. Darunee ${ }^{1^{*}} \&$ B. Tripob ${ }^{2}$ \\ ${ }^{1}$ Material Science Program, Membrane Science Technology Research Center, Faculty of Science, \\ Prince of Songkla University (PSU), Songkhla 90112,Thailand \\ ${ }^{2}$ Department of Physics, Prince of Songkla University 90112, Thailand
}

\begin{abstract}
Porous alumina membranes were prepared from alumina matrix, polyvinyl alcohol binder (1-5\%) and calcium carbonate additive $(0-3 \%)$. The disc-shaped alumina samples were fabricated by slip casting process. The alumina paste was sintered at different temperatures of $1100,1200,1300$ and $1400^{\circ} \mathrm{C}$. The results showed that the porosity of the porous membrane reached $45 \%-46 \%$ at $1300^{\circ} \mathrm{C}$ sintering for the mixtures of alumina matrix with $3 \%$ PVA and alumina matrix with $2 \% \mathrm{CaCO}_{3}$ plus $3 \%$ PVA. The water permeability was $150 \mathrm{~L} / \mathrm{m}^{2}$.h at $20 \mathrm{kPa}$ and the hydraulic conductivity coefficient was $1.06 \times 10^{-9}-2.43 \times 10^{-9} \mathrm{~ms}^{-1} \mathrm{~Pa}^{-1}$. The density, linear shrinkage water absorption and mechanical strength were ca. $3.92 \mathrm{~g} / \mathrm{cm}^{3}, 1.61-1.71 \%$ and $20.45-21.92 \%, 17.26-21 \mathrm{MPa}$, respectively. The SEM micrographs of alumina membrane using PVA binder showed a dense surface layers. An increase of the PVA binder resulted in a higher pure water fluxes and bigger pore sizes. An increase of $\mathrm{CaCO}_{3}$ in a 3\% $\mathrm{PVA}$ binder mixtures resulted in a little decrease of porosity but increase in linear shrinkage from 1.57 to $2.04 \%$ at $1300^{\circ} \mathrm{C}$ sintering.
\end{abstract}

Keyzords: Porous ceramics membrane, alumina, calcium carbonate, polyvinyl alcohol, slip casting

\subsection{INTRODUCTION}

The porous ceramics have been used for thermal insulation purpose as building materials for a long time. Nowadays, the use of ceramics membranes in separation processes has rapidly increased. Applications of porous ceramic as filters, catalyst supports and membranes are rapidly growing in the fields of environment, chemistry, biotechnology, foods processing and wastewater treatment. They can be used in harsh environments due to their high thermal and chemical stabilities and high mechanical strength. These porous ceramic membranes have attracted significant interest because of their potential uses in high temperature applications [1-4]. The properties (phase structure, mechanical strength, and the pore structure) of a thermally stable

* Correspondence to: B. Darunee (email: darunee.b@psu. ac.th) membrane remain unchanged at high temperatures for a period of time [4].

For the uses in separation processes, the mesoporous ceramic membranes are deposited onto a macroporous ceramic support. Generally, ceramics membranes have a multi-layer structure including the substrate or support layer. The ceramics membrane supports can be prepared by several methods such as extrusion, slip casting, and isostatic pressing [5-8]. Slip casting is one of the most useful forming methods and is widely applied for the commercial production of ceramics because it is able to form compacts with large size and complex shape easily. In this process, the dispersion of ceramic powder in aqueous medium is required.

This work aimed at the preparation of ceramic membrane made of $99.4 \%$ alumina powder matrix, and studied the effects of calcium carbonate as a pore promoter or sintering aid and the effects of polyvinyl alcohol as a binder in the 
alumina matrix by slip casting method, at various sintering temperatures. Technological propertie of the supports such as water permeability, porosity, pore size, morphology and structural strength were studied and reported.

\subsection{EXPERIMENTAL PROCEDURE}

The raw materials used were alumina $99.4 \%$ calcium carbonate (Merck, Germany) additive and polyvinyl alcohol (PVA, Fluka 81383) Varying proportion of PVA binder of 1, 3 and $5 \%$ was chosen and coded 1 PVA, 3 PVA and 5 PVA, respectively. Similarly to the percentage of $\mathrm{CaCO}_{3}$ additive of 1,2 and $3 \%$ was chosen and coded with the PVA proportions $1 \mathrm{CaCO}_{3} 3 \mathrm{PVA}$, $2 \mathrm{CaCO}_{3} 3$ PVA, $3 \mathrm{CaCO}_{3} 3$ PVA. The selected mixture formula was given in Table 1. Each mixture was wet grinding for 24 hour aging for 1 day, cont sity $85-100 \mathrm{cp}$ by Brookfield meter. At each mixture formula, totally 15 disc-shaped samples of $4.8 \mathrm{~cm}$ diameter and $0.3 \mathrm{~cm}$ thick were prepared by the slip casting method. The samples were then oven-dried at $110^{\circ} \mathrm{C}$ until constan weight, and sintering at temperatures 1100,1200 , 1300 and $1400^{\circ} \mathrm{C}$ for $1 \mathrm{~h}$ (heating at $4^{\circ} \mathrm{C} / \mathrm{m}$ 1300 and $1400{ }^{\circ} \mathrm{C}$. $1 \mathrm{~h}$ (heting at $4^{\circ} \mathrm{C} / \mathrm{min}$ up to $600^{\circ} \mathrm{C}$, and at $4^{\circ} \mathrm{C} / \mathrm{min}$ from 600 to $1100-$
$1400^{\circ} \mathrm{C}$, and naturally cooled.

The linear shrinkage was determined according to the standard method ASTM C326 [9], upon firing, of the tested samples. Water absorption and related properties were determined following the

Table 1 Six mixtures formula of alumina matrix, PVA binder (1-5\%) and calcium carbonate additive $(0-3 \%)$ showing individua component weight percentage

\begin{tabular}{cccc}
\hline $\begin{array}{c}\text { Mixture } \\
\text { codes }\end{array}$ & $\begin{array}{c}\text { Alumina } \\
(\mathbf{\% )}\end{array}$ & $\begin{array}{c}\text { PVA } \\
\mathbf{( \% )}\end{array}$ & $\begin{array}{c}\mathrm{CaCO}_{3} \\
\mathbf{( \% )}\end{array}$ \\
\hline 1 PVA & 99 & 1 & - \\
$3 \mathrm{PVA}$ & 97 & 3 & - \\
$5 \mathrm{PVA}$ & 95 & 5 & - \\
$1 \mathrm{CaCO}_{3} 3 \mathrm{PVA}$ & 96 & 3 & 1 \\
$2 \mathrm{CaCO}_{3} 3 \mathrm{PVA}$ & 95 & 3 & 2 \\
$3 \mathrm{CaCO}_{3} 3 \mathrm{PVA}$ & 94 & 3 & 3
\end{tabular}

standard method ASTM C373-88 (2006) [10] For each mixture the average property value was taken from five samples tested. The bulk density of the samples was measured by the water suspension method using Archimedes' principle. The morphology of phases and the microstructure (SEM; JOEL Model JSM-58000LV, Japan).

\subsection{RESULTS AND DISCUSSIONS}

3.1 Effect of Organic Additive (PVA) and $\mathrm{CaCO}_{3}$

The shrinkage of sintered support was observed in Figure 1(a). The shrinkage of the sample

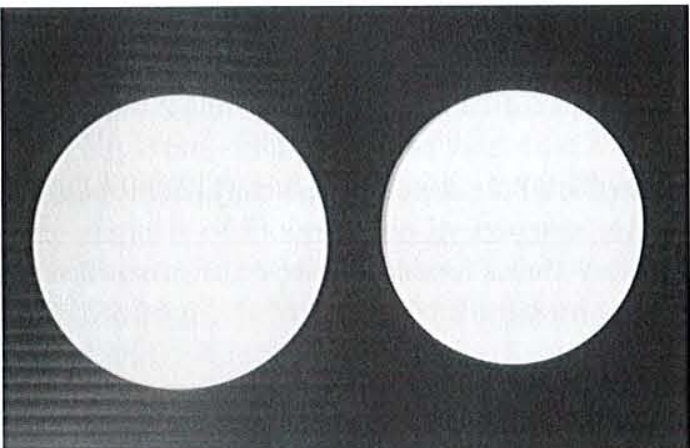

(a)

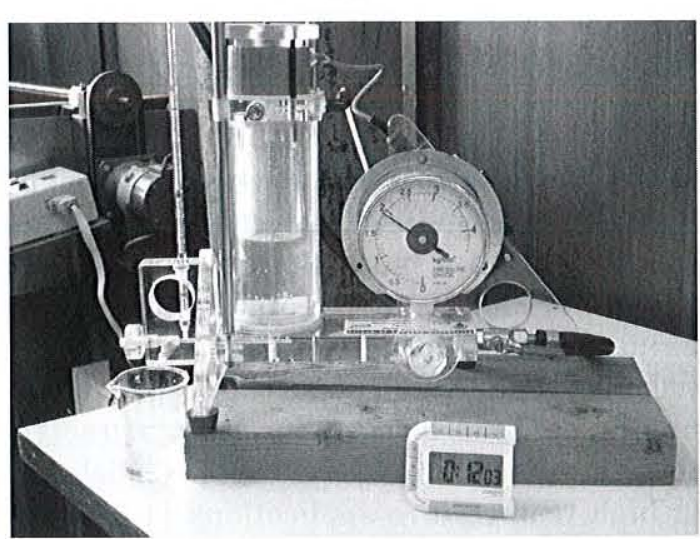

(b)

Figure 1 Preparation of porous ceramic from alumina (a) disc-shaped samples and (b) dead-end cell for PWF tes sintered at $1400^{\circ} \mathrm{C}$ decreased from $4.3 \%$ to $3.9 \%$ as the PVA content increased (Figure 2(a)). Addition of $\mathrm{CaCO}_{3}$ content of $1,2,3 \%$ with fixed $3 \%$ PVA in alumina increased the shrinkage of the tested samples (Figure 2(b)) at the increasing sintering temperatures.

The porosity of the samples of 1-3-5\% PVA sintered at temperatures 1100 and $1200^{\circ} \mathrm{C}$ ranged $45-52 \%$ but lower the porosity at higher sintering temperatures of 1300 and $1400^{\circ} \mathrm{C}$ (Figure 3(a)). Addition of $\mathrm{CaCO}_{3}$ of $1-3 \%$ behaved as a sintering aid clearly at higher sintering temperatures (Figure 3(b)).

The water absorption of the samples was gene-

ncreased. For examples, the samples with $1 \%$ PVA, the water absorption was $26.00,24.29$, 20.69 and $17.14 \%$ for $1100,1200,1300$ and $1400^{\circ} \mathrm{C}$, respectively (Figure $\left.4(\mathrm{a})\right)$.

\subsection{Flexural Strength 3-point Bending} Strength Test

Figure 5 shows the three-point bending strength of the samples sintered at different temperatures $\left(1100-1400^{\circ} \mathrm{C}\right)$. The strength was enhanced with the increase of sintering temperature in the range of $1100-1400^{\circ} \mathrm{C}$. When the temperature was above $1200^{\circ} \mathrm{C}$, the strength of sample increased rally decreased when the sintering temperatures abruptly from 5 to $16 \mathrm{MPa}$. We concluded that

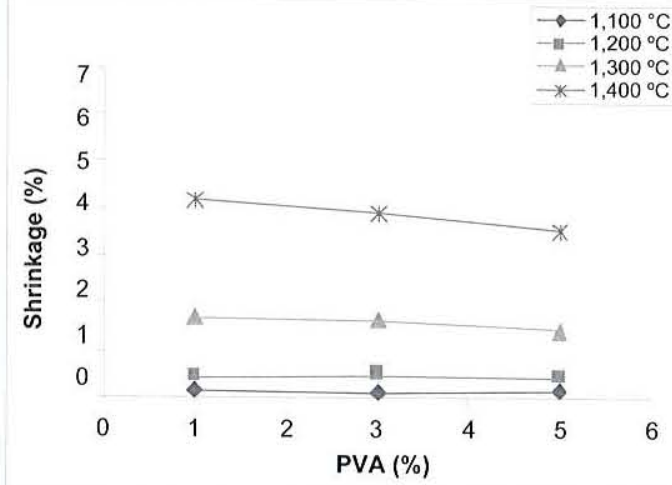

(a)

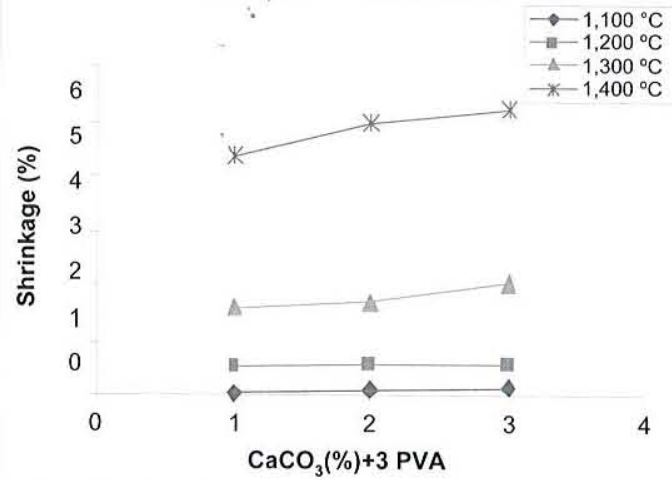

(b)
Figure 2 Effect of shrinkage of the samples prepared at different sintering temperatures, from (a) the mixture coded 1-3-5 PVA, (b) the mixture coded 1-2-3 $\mathrm{CaCO}_{3} 3 \mathrm{PVA}$

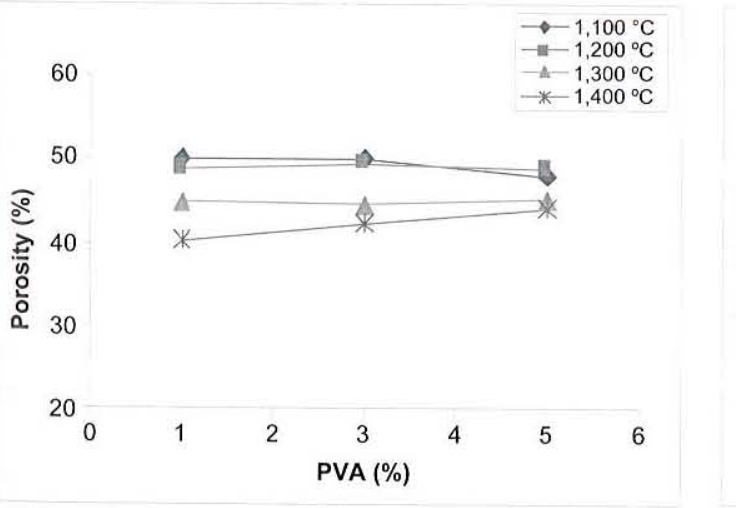

(a)

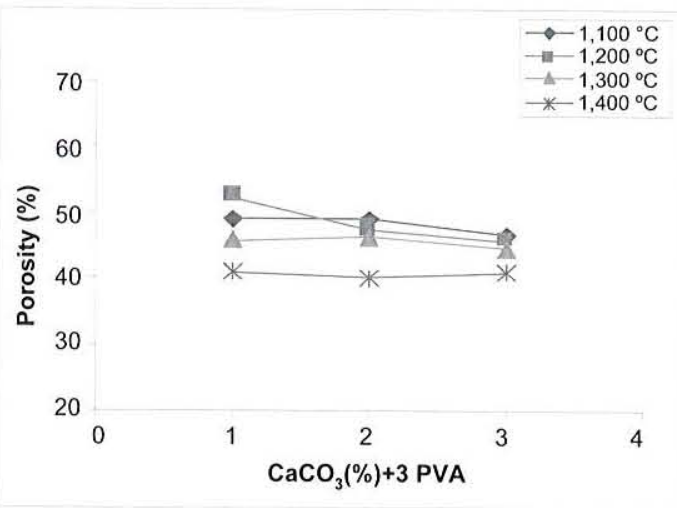

(b)
Figure 3 Effect of porosity of the samples prepared at different sintering temperatures, (a) from the mixture coded 1-3-5 PVA, (b) from the mixture coded 1-2-3 $\mathrm{CaCO}_{3} 3$ PVA 


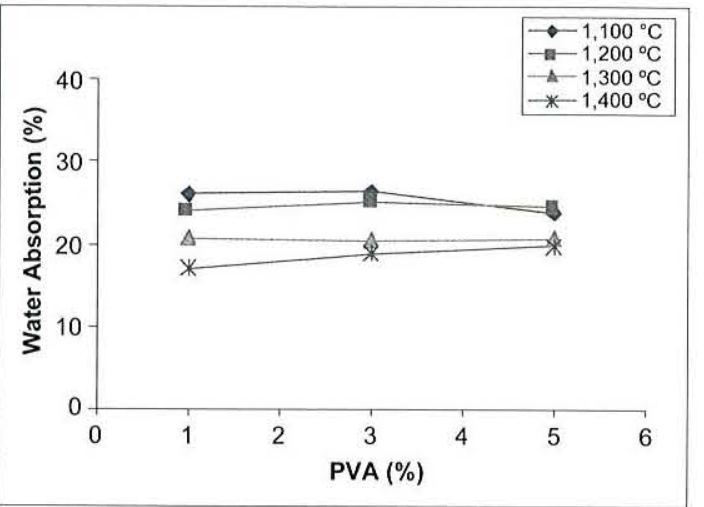

(a)

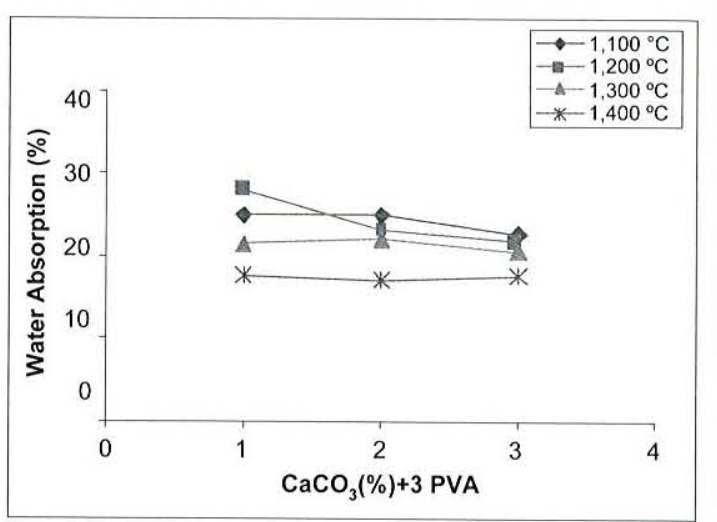

(b)
Figure 4 Effect of water absorption of the samples prepared at different sintering temperatures, (a) from the mixture coded 1-3-5 PVA, (b) from the mixture coded 1-2-3 $\mathrm{CaCO}_{3} 3$ PVA

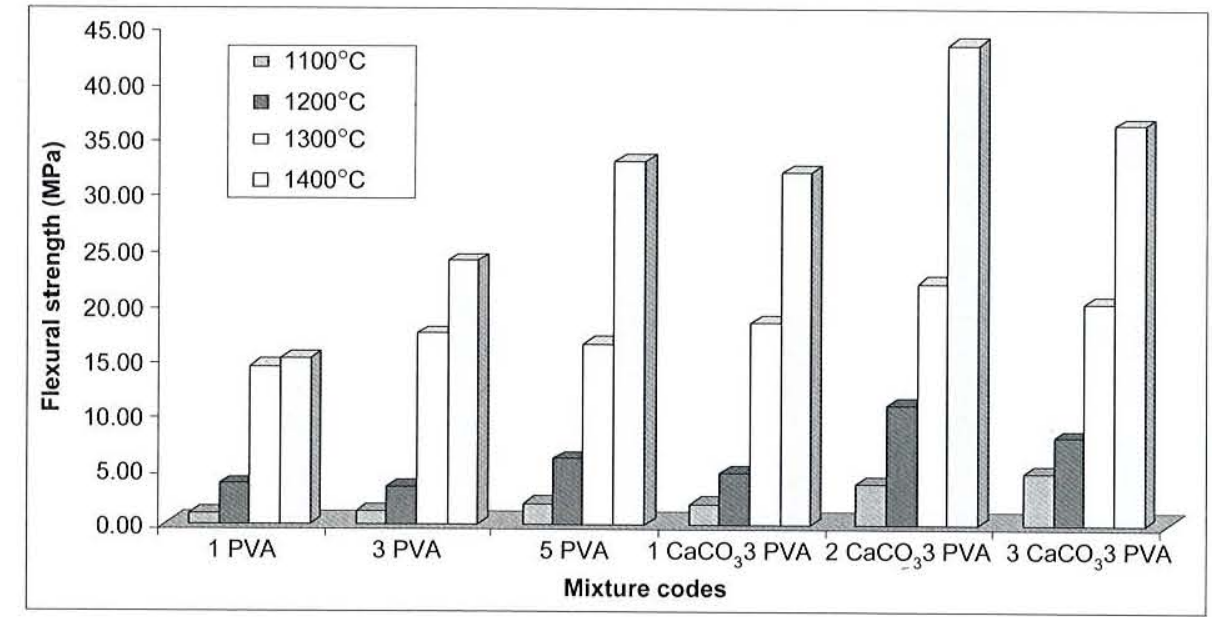

Figure 5 Strength of the samples prepared from the mixture coded 1, 3, 5 PVA and 1 , 2, $3 \mathrm{CaCO}_{3} 3 \mathrm{PVA}$ at different sintering temperatures

sintering temperatures of less than $1200^{\circ} \mathrm{C}$ could not produce a high siength for a support. The highest strength of $43 \mathrm{MPa}$ was observed for samples coded $2 \mathrm{CaCO}_{3} 3$ PVA at firing temperature of $1400^{\circ} \mathrm{C}$. At this temperature, the porosity and water absorption were reduced to $39 \%$ and $16 \%$, respectively, which were probably due to a high content of $\mathrm{CaCO}_{3}$. At such high temperature $\mathrm{CaCO}_{3}$ probably behaved as a sintering aid instead of a pore promoter. This resulted in a lower in porosity and water absorption while the strength of the $300^{\circ} \mathrm{C}, \mathrm{CaCO}_{3}$ behaved as a pore promoter $\mathrm{du}$ to the transformation of $\mathrm{CaCO}_{3}$ to $\mathrm{CaO}$ and $\mathrm{CO}_{2}$ [11]. Addition of PVA in alumina increased the strength of the samples at the same temperature and increasing amount of $\mathrm{CaCO}_{3}$ in the mixtures with 3 PVA resulted in farther increase of the strength, especially at $1400^{\circ} \mathrm{C}$, while the porosity reduced.

We concluded that the best mixtures selected for preparation of porous alumina with the porosity of $45 \%$ and strength 18-21 MPa were samples was increased. At a temperatures below
3.3 Pure Water Flux Test

The pure water flux (PWF) is measured unde steady-state flow using the equation, $J_{z}=Q / A \Delta T$

(1), Where, $J_{w}$ is the water flux $\left(\mathrm{L} \mathrm{m}^{-2} \mathrm{~h}^{-1}\right), \mathrm{Q}$ is the quantity of water permeated (litre) during the

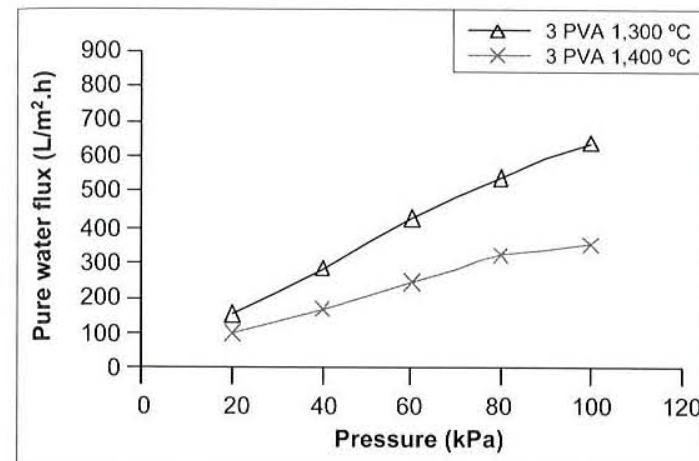

(a)

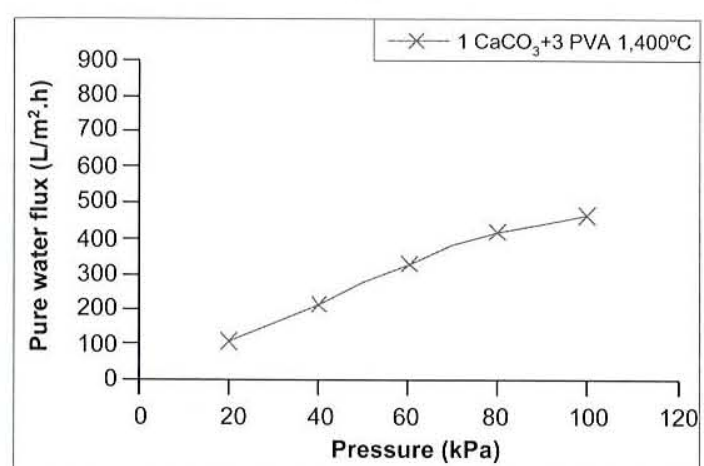

(c) sampling time $\Delta T$ (hour) and $A$ is the membrane area $\left(\mathrm{m}^{2}\right)$

The hydraulic resistance of the membrane is determined by measuring the PWF at different transmembrane pressure $(\Delta P)$, ranged $20-100 \mathrm{ps}$ $(142-689 \mathrm{kPa})$. The membrane hydraulic resis-

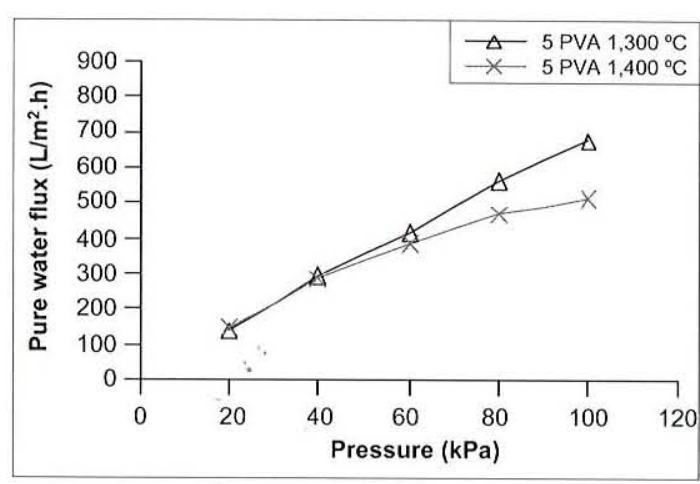

(b)

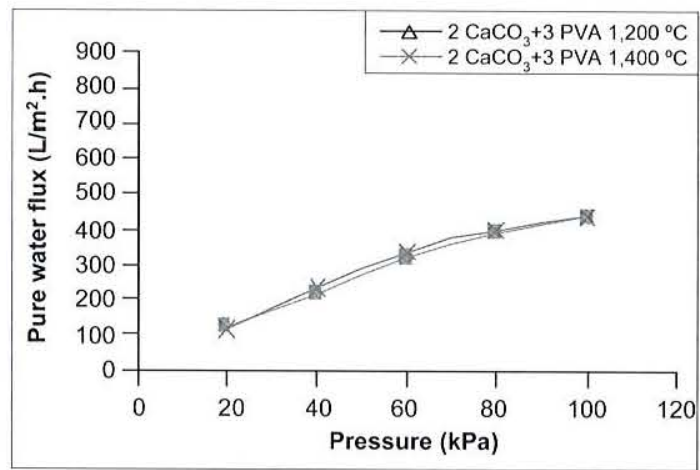

(d)

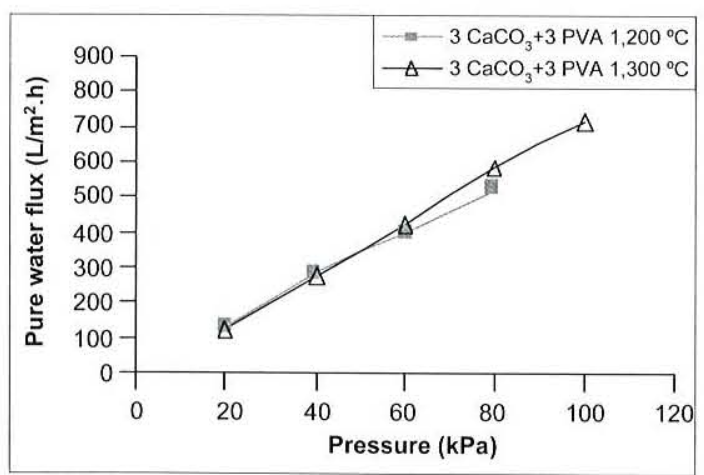

(e)

Figure 6 Pure water flux vs. pressure of the tested samples of the mixture coded (a) 3 PVA, (b) 5 PVA (c) $1 \mathrm{CaCO}_{3} 3$ PVA, (d) $2 \mathrm{CaCO}_{3} 3 \mathrm{PVA}$ and (e) $3 \mathrm{CaCO}_{3} 3 \mathrm{PVA}$ 
tance $\left(R_{m}\right)$ is evaluated from the slope of the PWF versus transmembrane pressure difference $(\Delta P)$. Slope of the graph is the hydraulic conductivity coefficient $\left(L_{p}\right)$. The equations are the following $J_{w}=\Delta P / R_{m}(2)$ and $J_{w}=L_{p} \Delta P(3)$, Where $J_{w}$ is the water flux $\left(1 / \mathrm{m}^{2} \mathrm{~h}\right)$

Figure 6 showed the effect of operating pressure on the pure water flux. Result indicated

a linearly dependence of the pure water fluxes on pressures, especially at low pressures. At a high pressure some samples showed a little decrease of PWF which was observed as a non linear portion of the curves. The PWF becomes low in the case of low pressure at steady state flow. We investigated and found the transparent cake laye on the support surface even in the pure water flux studies. The cake layer on the support surface became a thin layer and gave a low permeation resistance at low pressure. On the other hand, a a high pressure the permeation fluxes were high and the cake layer on the support surface became thick and resulted in a lower the PWF because of a high permeation resistance [12]. Cake laye found on the support surface after some hours of the PWF tests was probably a bio-film which grew very quick in our humid environment.

Samples from mixture coded 3 PVA sintered at $1300^{\circ} \mathrm{C}$ had a higher PWF $\left(280 \mathrm{~L} / \mathrm{m}^{2} \mathrm{~h}\right)$ than those sintered at $1400^{\circ} \mathrm{C}\left(164 \mathrm{~L} / \mathrm{m}^{2}\right.$.h; Figure $6(a))$ at the operating pressure $40 \mathrm{kPa}$. No PWF difference was observed when compared with those of samples coded 5 PVA (Figure 6(b)) Addition of $\mathrm{CaCO}_{3} 1-3 \%$ did not increase the PWF of the tested samples (Figure 9(c), 9(d), 9(e)). The results indicated the highest PWF were obtained from samples prepared from the mixture coded 3 PVA $\left(641 \mathrm{~L} / \mathrm{m}^{2} . \mathrm{h}\right)$ and 5 PVA $\left(679 \mathrm{~L} / \mathrm{m}^{2} . \mathrm{h}\right)$ with sintering temperature of $1300^{\circ} \mathrm{C}$ at $100 \mathrm{kPa}$. Table 2 showed the hydraulic

Table 2 Hydraulic conductivity coefficient $\left(L_{p}\right)$ of the product ceramic membranes

\begin{tabular}{cc} 
Product Membrane code & $\boldsymbol{L}_{\boldsymbol{p}}\left(\mathbf{m} \cdot \mathbf{s}^{-1} \cdot \mathbf{P a}^{-1}\right)$ \\
\hline 3 PVA & $1.06 \times 10^{-9}$ \\
5 PVA & $1.59 \times 10^{-9}$ \\
$1 \mathrm{CaCO}_{3}$ 3 PVA & $1.39 \times 10^{-9}$ \\
$2 \mathrm{CaCO}_{3} 3 \mathrm{PV}$ & $1.35 \times 10^{-9}$
\end{tabular}

conductivity coefficients $(L)$ of the product membranes. The result indicated that the membranes coded 3 PVA, 5 PVA, $1 \mathrm{CaCO}_{3} 3$ PVA and $2 \mathrm{CaCO}_{3} 3$ PVA can be used as a filtration membrane or as a porous support.

\subsection{Morphological Studies}

The cross-sectional, top surface and botton support surface morphology of our alumin membrane were examined using a scannin electron microscope at different magnifications. Figures 7-10 showed the cross-sectional, top surface and bottom surface views of the produced ceramic membrane at different formula. It seemed clear that during the slip casting the fine particle combined with the PVA started to float to the top surface and produced the smaller pores at the top surface (Figures 7(b), 8(b), 9(b) and 10(b)) compared with the pores at the bottom surface estimated from in Table 3.

SEM images of sample formula coded 3 PVA showed the pore sizes ranged $0.8-1.5 \mu \mathrm{m}$ at the top surface (Figure $7(\mathrm{~b})$ ) and 1-2.5 $\mu \mathrm{m}$ at the bottom support surface (Figure 7(c)). For formula coded 5 PVA, partial fusion was clearly seen and the pore sizes reduced to $0.15-2.0 \mu \mathrm{m}$ (Figure $8(\mathrm{~b}))$ while the pore sizes at the bottom surface were similar to those at 3 PVA (Figure $8(\mathrm{c})$ ) Addition of $1 \% \mathrm{CaCO}_{3}$ in formula coded $1 \mathrm{CaCO}_{3} 3$ PVA clearly showed a fusion enhancing effect of calcium carbonate and resulted in finer pore sizes $(0.1-0.5 \mu \mathrm{m})$ and particle sizes at the top surface (Figure 9(b)). Similarly, the fines

Table 3 Pore sizes at top and bottom surfaces of samples of different mixtures

\begin{tabular}{cccc}
$\begin{array}{c}\text { Mixture } \\
\text { codes }\end{array}$ & $\begin{array}{c}\text { Top surface } \\
\text { pore }(\mu \mathrm{m})\end{array}$ & $\begin{array}{c}\text { Bottom } \\
\text { surface } \\
\text { pore }(\mu \mathrm{m})\end{array}$ & Reference \\
\hline $3 \mathrm{PVA}$ & $0.8-1.5$ & $1-2.5$ & Figure 6 \\
$5 \mathrm{PVA}^{-1.5}$ & $0.15-2.0$ & $1-2.5$ & Figure 7 \\
$\mathrm{CaCO}_{3} 3 \mathrm{PVA}$ & $0.1-0.5$ & $0.1-1.5$ & Figure 8 \\
$\mathrm{CaCO}_{3} 3 \mathrm{PVA}$ & $0.05-0.3$ & & Figure 9 \\
\hline
\end{tabular}

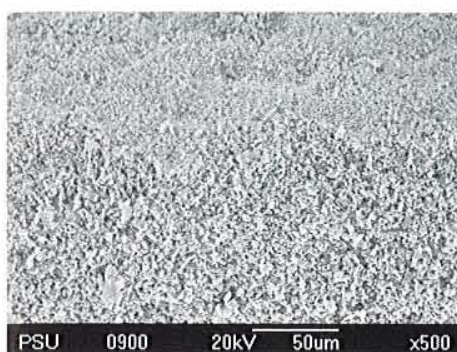

(a)

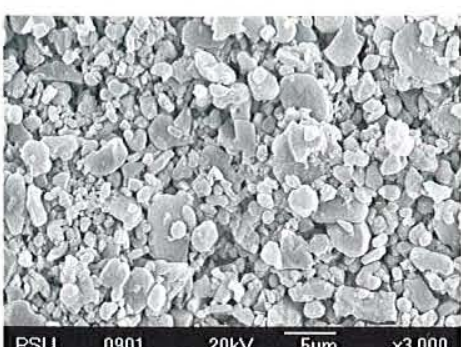

(b)

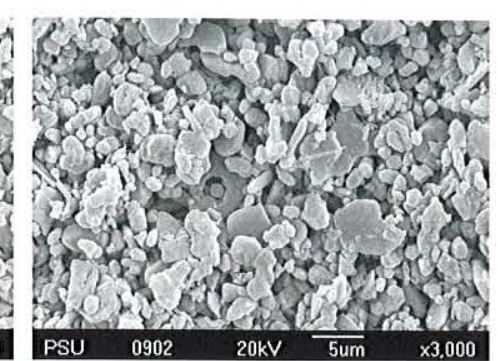

(c)
Figure 7 The SEM images of the sample mixture formula coded 3 PVA sintered by $1200^{\circ} \mathrm{C}$ (a) crosssection (b) top surface and (c) bottom support surface views

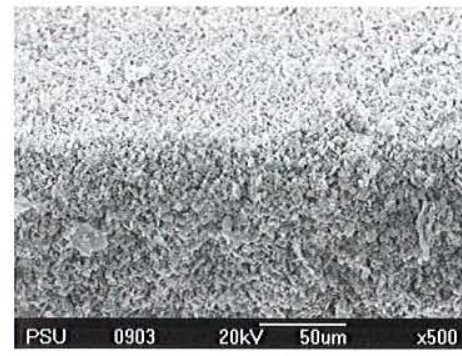

(a)

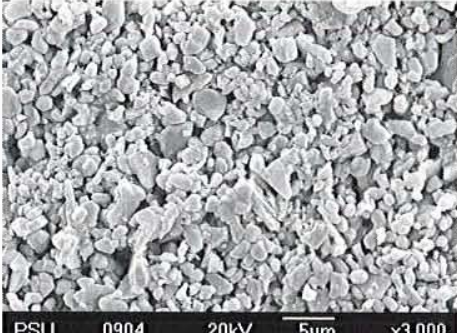

(b)

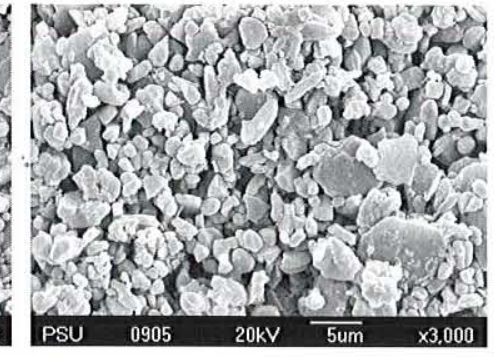

(c)
Figure 8 The SEM images of the sample mixture formula coded 5 PVA sintered by $1200^{\circ} \mathrm{C}$ (a) crosssection (b) top surface and (c) bottom support surface views

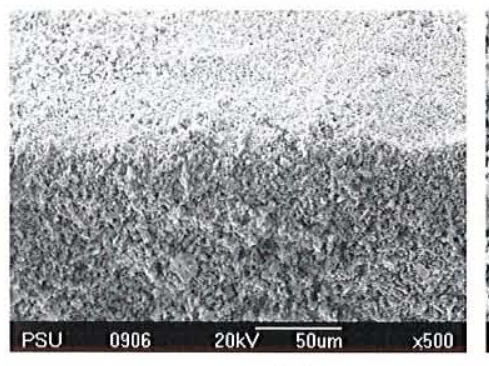

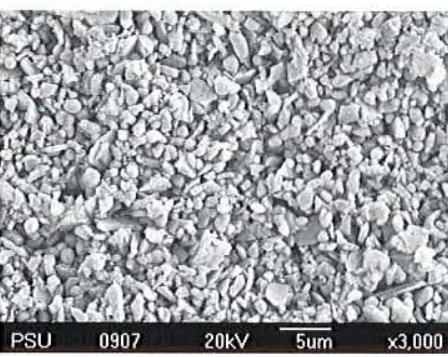

(b)

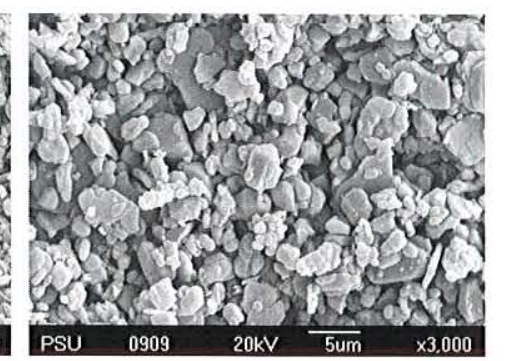

Figure 9 The SEM images of the sample mixture coded $1 \mathrm{CaCO}_{3} 3$ PVA sintered by $1200^{\circ} \mathrm{C}$ (a) crosssection (b) top surface and (c) bottom support surface views

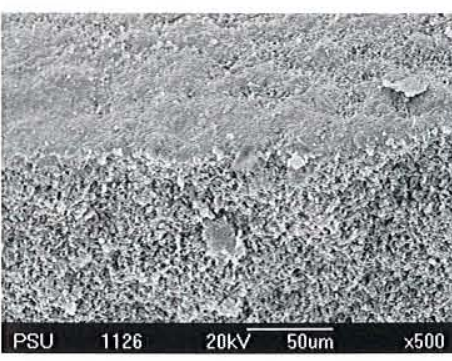

(a)

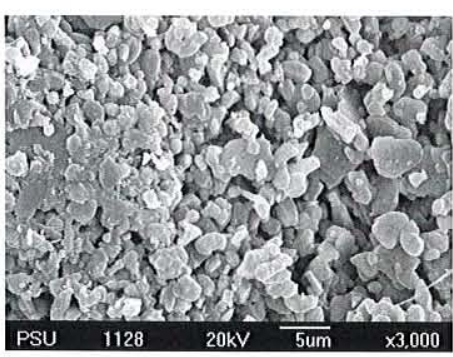

(b)

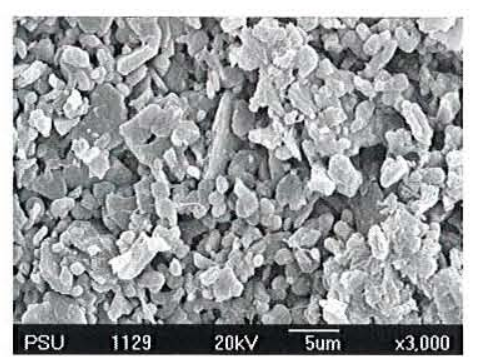

(c)
Figure 10 The SEM images of the sample mixture coded $3 \mathrm{CaCO}_{3} 3 \mathrm{PVA}$ sintered by $1400^{\circ} \mathrm{C}$ (a) crosssection (b) top surface and (c) bottom support surface views 
pore sizes $(0.05-0.3 \mu \mathrm{m})$ at the top surface were resulted for the formula coded $3 \mathrm{CaCO}_{3} 3$ PVA sintered at temperature $1400^{\circ} \mathrm{C}$ (Figure $10(\mathrm{~b})$ ).

\subsection{CONCLUSIONS}

The results showed that the highest porosity of the product porous membrane reached $45 \%-46 \%$ at $1300^{\circ} \mathrm{C}$ sintering for the alumina sample mixtures coded 3 PVA and $2 \mathrm{CaCO}_{3} 3 \mathrm{PVA}$. The water permeability was $150 \mathrm{~L} / \mathrm{m}^{2} \mathrm{~h}$ at $20 \mathrm{kPa}$ and the $L$ was $1.06 \times 10^{-9}-2.43 \times 10^{-9} \mathrm{~ms}^{-1} \mathrm{~Pa}^{-1}$. the $L_{p}$ was 1.06 The linear shrinkage and water absorption and mechanical strength were ca. 1.61-1.71\%, 20.45 $21.92 \%$ and $17.26-21 \mathrm{MPa}$, respectively. The SEM micrographs of alumina membrane using PVA binder showed a denser surface layer when compared with the bottom support surface. An increase of the PVA binder resulted in a higher increase of the PVA binder resulled in a highe pure water fluxes and bigger pore sizes. An
increase of $\mathrm{CaCO}_{3}$ in a 3\% PVA binder mixtures resulted in a little decrease of porosity but increase in linear shrinkage from 1.57 to $2.04 \%$ at $1300^{\circ} \mathrm{C}$ sintering.

Porous alumina support produced in this work has been further used in liquid effluent processing as well as in improving water drinking ability. Such supports will be tested in the removing polluting metallic species in wastewater produced by surface treatment in industry. Some kinds of composite membrane produced using alumina support will be tested for skim latex concentration.

\section{ACKNOWLEDGEMENTS}

The authors appreciate the financial support from the Prince of Songkla University. The authors also wish to thank the Material Science Program, Membrane Science and Technology Research Center and Graduate School, Prince of Songkla University for supporting facilities and funding.

\section{REFERENCES}

[1] Lin, Y.-S., and A.J. Burggraaf. 1991. Preparation and Characterization of High-
Temperature Thermally Stable Alumina Composite membrane. J. Am. Ceram. Soc. 74: 219-224.

[2] Lin, Y.-S., C.-H. Chang, and R. Gopalan. 1994. Improvement of Thermal Stability of Porous Nanostructured Ceramic of Porous Nanstructured Ceramic Membranes. Ind. Eng. Chem. Res. 33: 860-
870.

[3] Boissière, C., L. Nicole, C. Gervais, F Babonneau, M. Antonietti, H. Amenitsch, C. Sanchez, and D. Grosso. 2006. Nanocrystalline Mesoporous ?-Alumina Powders "UPMC1 Material" Gathers Thermat and Chemical Stability with High Surface Area.
Chem. Mater. 18: 5238-5243.

[4] Kim, S.M., Y.-J. Lee, K.-W. Jun, J. -Y. Park and H.S. Potdar. 2007. Synthesis of Thermo-stable High Surface Area Alumina Powder from Sol-gel Derived Boehmite. Mater: Chem. Phys. 104: 56-61.

[5] Babaluo, A.A., M. Kokabi, M. Manteghian, and R. Sarraf-Mamoory. 2004. A Modified Model for Alumina Membranes Formed by Gel-casting Followed by Dip-coating. J. Eur. Ceram. Soc. 24: 3779-3787.

[6] Lyckfeldt, O., and J.M.F. Fereira, 1998. Processing of Porous Ceramics by Starch Consolidation. J. Eur: Ceram. Soc. 18: 131-
140.

[7] Das, N., and H.S. Maiti. 1998. Formation of Pore Structure in Tape-cast Alumina Membranes - effects of Binder Content and Firing Temperature. J. Mem. Sci. 140: 205212.

[8] Ahmad, A.L., N.F. Idrus, and M.R. Othman, 2005. Preparation of Perovskite Alumina Ceramic Membrane using Sol-gel Method. J. Mem. Sci. 262: 129-137.

[9] ASTM Standard C326-03. "Standard Tes Method for Drying and Firing Shrinkages of Ceramic Whiteware Clays." ASTM International, West Conshohocken, PA. www.astm.org.

[10] ASTM C373-88. 2006. "Standard Tes Method for Water Absorption, Bulk Density, Apparent Porosity, and Apparen Specific Gravity of Fired Whiteware Products." ASTM International, West Conshohocken, PA. www.astm.org.
[11] Falamaki, C., M. Naimi, and A. Aghaie, 2004. Dual Behavior of $\mathrm{CaCO}_{3}$ as a Porosifier and Sintering Aid in the Manufacture of Alumina Membrane/catalyst Supports. J. Eur: Ceram. Soc. 24: 3195-3201.
[12] Belouatek, A., A. Ouagued, M. Belhakem, and A. Addou. 2008. Filtration Performance of Microporous Ceramic Supports. $J$ Biochem. Biophys. Methods. 70: 11741179 . 